\title{
ASSESSMENT OF THE THERAPEUTIC AND ANTICONVULSIVE EFFICACY OF A DRUG COMBINATION CONSISTING OF TRIHEXYPHENIDYLE AND HI-6 IN SOMAN-POISONED RATS
}

\author{
Jiři Kassa ${ }^{1}$, Ivan Samnaliev ${ }^{2}$ \\ Purkyně Military Medical Academy in Hradec Kralové, Czech Republic: Department of Toxicology ${ }^{1}$; Military Medical \\ Academy, Sofia, Bulgaria: Research Center of NBC Defence ${ }^{2}$ \\ Summary: 1. The influence of two anticholinergic drugs (atropine, trihexyphenidyle) on the effectiveness of antidotal treat- \\ ment to eliminate soman-induced lethal effects and convulsions was studied in rats. 2. The oxime HI-6 when combined \\ with centrally acting anticholinergic drug trihexyphenidyle seems to be more efficacious in the elimination of acute toxic \\ effects of soman than its combination with atropine. 3. The findings support the hypothesis that the choice of the anti- \\ cholinergic drug is important for the effectiveness of antidotal mixture in the case of antidotal treatment of soman-induced \\ acute poisoning.
}

Key words: Soman; Atropine; Trihexyphenidyle; HI-6; Acute toxicity; Convulsions; Rats

\section{Introduction}

Despite the entry into force in April 1997 of the Chemical Weapons Convention forbidding the development, production, stockpiling and use of chemical warfare agents, the world has seen a rapid proliferation of such agents (18). The chemical warfare agents include different types of chemicals. The most important groups are nerve agents, highly toxic organophosphorus compounds (OPs) that exert their toxic effects by irreversible inhibiting the enzyme acetylcholinesterase (AChE, EC 3.1.1.7), which leads to excessive accumulation of acetylcholine ( $\mathrm{ACh}$ ) in cholinergic synapses including neuromuscular junctions. The overstimulation of cholinergic receptors results in toxic signs and symptoms of fasciculations, twitching, glandular hypersecretion, convulsions and respiratory failure (13). The standard antidotal treatment of acute intoxication with nerve agents consists of anticholinergic drugs to counteract the accumulation of $\mathrm{ACh}$ and oximes to reactivate OP-inhibited AChE $(4,13)$. Unfortunately, certain OPs are rather resistant to the standard antidotal treatment.

Soman (O-pinacolyl methylphosphonofluoridate) is an extremely toxic, centrally and peripherally acting nerve agent, which produces $\mathrm{ACh}$ accumulation leading to severe respiratory distress, prolonged limbic seizure, generalized convulsions and subsequent neuropathology in the brain (14). It appears to be one of the most resistant OPs to oxime reactivation because of rapid aging of soman-inhibited AChE that makes the complex inhibitor-enzyme resistant to the re- activators of cholinesterase and because of the existence of a soman depot in the poisoned organisms $(1,4,6,7)$.

As the convulsions produced by soman may lead to brain lesions and delayed neuropathy in survivors, a successful therapy should be able not only to protect the victims from the lethal effects of soman but also to diminish or eliminate the convulsive activity. Many studies have shown that the currently fielded cholinesterase reactivators such as 2-PAM and obidoxime are not able to assure a satisfactory protection against soman toxicity. Among cholinesterase reactivators, the bispyridinium oxime HI-6 has been shown to counteract relatively successfully the lethality caused by soman (10) but its efficacy to counteract soman-induced convulsions and subsequent neuropathy is not quite satisfactory. Therefore, the choice of the anticholinergic drug also plays a very important role for the efficacy of antidotal treatment of soman-induced conculsions because soman causes centrally mediated seizures activity that can rapidly progress to status epilepticus through the overstimulation of central muscarinic cholinergic receptors (14, 17). Commonly used cholinolytic drug atropine (ATR) possessing predominantly peripheral activity is not able to antagonize the toxic effects of soman in the central nervous system. On the other hand, some centrally acting anticholinergic drugs such as scopolamine, biperiden and benactyzine seem to be able to ameliorate soman-induced seizure activity and convulsions (22). It has been described that some centrally acting cholinolytic drugs such as benactyzine are able to increase the ability of HI-6 to re- 
activate soman-inhibited $\mathrm{AChE}$ in comparison with atropine (8).

The aim of the current study was to evaluate the antidotal and anticonvulsive efficacy of a drug combination consisting of cholinesterase reactivator HI-6 and centrally acting anticholinergic drug trihexyphenidyle (THP) in rats poisoned with lethal doses of soman. A comparative study using a second combination consisting of HI-6 and atropine as a standard cholinolytic drug was made.

\section{Methods}

Male albino Wistar rats from Military Medical Academy (MMA), Sofia weighing 180-220 g were used. They were kept in an air-conditioned room and allowed free access to standard food and tap water. During the experiments, the animals were divided as follow: 69 rats were used to determine the protective index (PI) and 44 rats were used for the assessment of anticonvulsive activity of the drug combinations tested.

Soman of $92 \%$ purity was used in the experiments. HI-6 of $99 \%$ purity was synthesized in the Laboratory of Experimental Toxicology of MMA, Sofia. All other chemicals and drugs of analytical grade were obtained commercially and used without further purification. All drugs were administered at a volume of $0.1 \mathrm{ml} / 100 \mathrm{~g}$ body weight.

Soman-poisoned rats were treated intramuscularly (i.m.) with the oxime HI-6 $(72 \mathrm{mg} / \mathrm{kg})$ in combination with atropine or THP one minute after the challenge of soman. THP and atropine were used in equimolar doses $-1.48 \times 10^{-2}$ mol. THP without cholinesterase reactivator was tested for protective efficacy as well. The therapeutic efficacy of tested antidotal mixtures was evaluated by the assessment of the $\mathrm{LD}_{50}$ values and their $95 \%$ confidence limits using probitlogarithmical analysis of death occuring within $24 \mathrm{~h}$ after i.m. administration of soman at five different doses with six rats per dose (21). The efficacy of tested antidotal mixtures was expressed as protective index $\left(\mathrm{LD}_{50}\right.$ value of soman in protected rats $/ \mathrm{LD}_{50}$ value of soman in unprotected rats).

To study the anticonvulsive efficacy of tested antidotal mixtures, two doses of soman - $1 \mathrm{LD}_{50}$ and $2 \mathrm{LD}_{50}$ were used to produce severe toxic signs including tonic-clonic convulsions. The anticonvulsive activity of the antidotal combination consisting of HI-6 and THP was evaluated at two time intervals - 1 min and 5 min after the challenge of soman. The second antidotal mixture consisting of HI-6 and atropine was applied at the same conditions. Soman and antidotes were administered intramuscularly. The first experiment was carried out on 10 rats per group, and six rats in group were used to determine the anticonvulsive activity of the drug combinations applied 5 min after the challenge of soman.

The anticonvulsive efficacy was determined by using a seven degree scale for assessment of the toxic signs as follows: 0 - none of toxic signs, 1 - hyperactivity, 2 - shewing and/or salivation, 3 - fasciculations and/or tremors, 4 - subconvulsive movements, 5 - convulsions and 6 - death (19). The grade of the most severe signs observed was noted at 11 time points: 5,10, 15, 30, 60, 90, 120, 150, 180, 240 min and $24 \mathrm{~h}$ after the challenge. The severity score for each experimental group, presented as a sum of the average values obtained across the observations, was calculated. The lethality of soman was noted as well.

Statistical significance was determined by the use of Student's t-test and the differences were considered significant when $\mathrm{p}<0.05$.

\section{Results}

The results obtained from the protective study show that the combination consisting of THP and HI-6 is much more effective than the combination of HI- 6 with atropine. This combination administered $1 \mathrm{~min}$ after the challenge by soman provided significantly higher protective index, calculated $2 \mathrm{~h}(\mathrm{PI}=5.12)$ as well as $24 \mathrm{~h}(\mathrm{PI}=4.99)$ following soman poisoning than the second combination tested (Table 1). On the other hand, THP was ineffective in reducing soman toxicity when it was applied without cholinesterase reactivator.

Tab. 1: Protective efficacy of the antidotal combinations administered 1 min after intoxication with soman. * significantly different from the non-treated group at the level of $\mathrm{p}<0.05,{ }^{\mathrm{x}}$ significantly different from the group treated with HI-6 and atropine at the level of $\mathrm{p}<0.05$.

\begin{tabular}{|l|c|c|c|c|}
\hline TIME & $\begin{array}{c}1 \mathrm{LD}_{50} \\
\text { of Soman } \\
(\mu \mathrm{g} / \mathrm{kg}) \\
-2 \mathrm{~h}\end{array}$ & $\begin{array}{c}1 \mathrm{LD}_{50} \\
\text { of Soman } \\
(\mu \mathrm{g} / \mathrm{kg}) \\
-24 \mathrm{~h}\end{array}$ & $\begin{array}{c}\text { PI } \\
2 \mathrm{~h}\end{array}$ & $\begin{array}{c}\text { PI } \\
24 \mathrm{~h}\end{array}$ \\
\hline THP & $\begin{array}{c}88.3 \\
(70.2-92.7)\end{array}$ & $\begin{array}{c}69.1 \\
(64.0-74.4)\end{array}$ & 1.25 & 1.0 \\
\hline $\begin{array}{l}362.18^{*} \mathrm{x} \\
+ \text { THP }\end{array}$ & $\begin{array}{c}345.14^{*} \mathrm{x} \\
(335.7-390.7)\end{array}$ & 5.12 & 4.99 \\
\hline $\begin{array}{l}\text { HI-6 + } \\
\text { Atropine }\end{array}$ & $\begin{array}{c}221.0^{*} \\
(203.1-241.7)\end{array}$ & $\begin{array}{c}196.0^{*} \\
(180.9-212.4)\end{array}$ & 3.13 & 2.83 \\
\hline $\begin{array}{l}\text { Soman } \\
\text { (without } \\
\text { treatment })\end{array}$ & $\begin{array}{c}70.7 \\
(65.6-76.2)\end{array}$ & $\begin{array}{c}69.1 \\
(64.0-74.4)\end{array}$ & - & - \\
\hline
\end{tabular}

During the anticonvulsive study, the ability of the drug combinations tested to protect animals from soman-induced lethality was calculated as well. The rate of survivors was determined $24 \mathrm{hr}$ after soman challenge. The results obtained from these experiments are summarized in Table 2 and Table 3. They show that THP combined with HI-6 provided very good protection against soman-induced lethal effects when it is administered $1 \mathrm{~min}$ or $5 \mathrm{~min}$ after the administration of soman at lethal doses $\left(2 \mathrm{x} \mathrm{LD}_{50}\right.$ or $1 \mathrm{x}$ $\left.\mathrm{LD}_{50}\right)$. The $24-\mathrm{hr}$ mortality shows that only one animal died in the group intoxicated with the higher dose of soman. On the other hand, none of animals treated with atro- 
Tab. 2: Survival (\%) in experimental groups treated with the drug combinations tested 1 min after challenge with $2 \times \mathrm{LD}_{50}$ of soman.

\begin{tabular}{|l|c|c|c|c|c|c|c|c|c|}
\hline $\begin{array}{l}\text { Time } \\
\text { Groups }\end{array}$ & $5 \mathrm{~min}$ & $10 \mathrm{~min}$ & $15 \mathrm{~min}$ & $30 \mathrm{~min}$ & $1 \mathrm{~h}$ & $2 \mathrm{~h}$ & $3 \mathrm{~h}$ & $4 \mathrm{~h}$ & $24 \mathrm{~h}$ \\
\hline THP + HI-6 & 100 & 100 & 100 & 100 & 100 & 100 & 100 & 100 & 90 \\
\hline ATR + HI-6 & 100 & 100 & 100 & 90 & 70 & 60 & 50 & 50 & 0 \\
\hline Soman & 100 & 0 & 0 & 0 & 0 & 0 & 0 & 0 & 0 \\
\hline
\end{tabular}

Tab. 3: Survival (\%) in experimental groups treated with the drug combinations tested 5 min after challenge with $1 \times \mathrm{LD}_{50}$ of soman.

\begin{tabular}{|l|c|c|c|c|c|c|c|c|c|}
\hline $\begin{array}{l}\text { Time } \\
\text { Groups }\end{array}$ & $5 \mathrm{~min}$ & $10 \mathrm{~min}$ & $15 \mathrm{~min}$ & $30 \mathrm{~min}$ & $1 \mathrm{~h}$ & $2 \mathrm{~h}$ & $3 \mathrm{~h}$ & $4 \mathrm{~h}$ & $24 \mathrm{~h}$ \\
\hline THP + HI-6 & 100 & 100 & 100 & 100 & 100 & 100 & 100 & 100 & 100 \\
\hline ATR + HI-6 & 100 & 100 & 100 & 100 & 100 & 100 & 83.3 & 83.3 & 16.7 \\
\hline Soman & 100 & 83.3 & 50 & 50 & 50 & 50 & 50 & 50 & 16.7 \\
\hline
\end{tabular}

Tab. 4: Severity of intoxication in soman-poisoned rats treated with the oxime HI-6 in combination with THP or atropine administered $1 \mathrm{~min}$. after challenge with $2 \mathrm{x} \mathrm{LD}_{50}$ of soman.

\begin{tabular}{|c|c|c|c|c|c|c|c|c|c|c|}
\hline $\begin{array}{l}\text { Time } \\
\text { Group }\end{array}$ & $5 \mathrm{~min}$ & $10 \mathrm{~min}$ & $15 \mathrm{~min}$ & $0.5 \mathrm{~h}$ & $1 \mathrm{~h}$ & $1.5 \mathrm{~h}$ & $2 \mathrm{~h}$ & $3 \mathrm{~h}$ & $4 \mathrm{~h}$ & $24 \mathrm{~h}$ \\
\hline $\begin{array}{l}\text { HI-6 + THP } \\
(\mathrm{X} 1)\end{array}$ & $\begin{array}{r}1.95 \\
\pm 1.0 \\
* * * \\
(\dagger) \\
\end{array}$ & $\begin{array}{c}2.60 \\
\pm 0.7 \\
* * *\end{array}$ & $\begin{array}{c}2.90 \\
\pm 1.0 \\
* * *\end{array}$ & $\begin{array}{r}2.35 \\
\pm 0.9 \\
* * *\end{array}$ & $\begin{array}{r}2.50 \\
\pm 1.0 \\
* * *\end{array}$ & $\begin{array}{r}2.75 \\
\pm 0.8 \\
* * *\end{array}$ & $\begin{array}{r}2.65 \\
\pm 0.8 \\
* * *\end{array}$ & $\begin{array}{r}2.65 \\
\pm 0.6 \\
* * *\end{array}$ & $\begin{array}{r}2.75 \\
\pm 0.4 \\
* * *\end{array}$ & $\begin{array}{r}1.60 \\
\pm 2.2 \\
* * *\end{array}$ \\
\hline $\mathrm{X} 1: \mathrm{X} 2$ & $* * *$ & $* * *$ & $* *$ & $* * *$ & $* * *$ & $* * *$ & $* * *$ & $* * *$ & $* * *$ & $* * *$ \\
\hline $\begin{array}{l}\text { HI-6 + ATR } \\
(\mathrm{X} 2)\end{array}$ & $\begin{array}{r}4.00 \\
\pm 0.9\end{array}$ & $\begin{array}{c}4.35 \\
\pm 0.9 \\
* * * \\
(\dagger+)\end{array}$ & $\begin{array}{r}3.95 \\
\pm 0.7 \\
* * *\end{array}$ & $\begin{array}{c}4.30 \\
\pm 1.0 \\
* *\end{array}$ & $\begin{array}{c}4.50 \\
\pm 1.2 \\
* *\end{array}$ & $\begin{array}{c}4.95 \\
\pm 1.1 \\
*\end{array}$ & $\begin{array}{l}5.10 \\
\pm 1.0 \\
*\end{array}$ & $\begin{array}{r}5.30 \\
\pm 1.0\end{array}$ & $\begin{array}{r}5.25 \\
\pm 1.0\end{array}$ & 6.0 \\
\hline $\begin{array}{l}\text { Soman } \\
2 \mathrm{xLD}_{50} \\
(\mathrm{X} 3)\end{array}$ & $\begin{array}{r}2.50 \\
\pm 1.6\end{array}$ & 6.0 & 6.0 & 6.0 & 6.0 & 6.0 & 6.0 & 6.0 & 6.0 & 6.0 \\
\hline
\end{tabular}

Statistical significance: $*-p<0.05 ; * *-p<0.01 ; * * *-p<0.001 ;(\dagger)-$ comparison between X1 and X3; $(\dagger \dagger)-$ comparison between $\mathrm{X} 2$ and $\mathrm{X} 3$

pine and HI-6 1 min after the administration of soman at the dose corresponding to $2 \mathrm{x} \mathrm{LD}_{50}$ survived within $24 \mathrm{hr}$. This antidotal mixture was practically ineffective in reducing soman lethality when was applied 5 min after exposure to $1 \mathrm{x} \mathrm{LD}_{50}$ of soman. Only one animal $(16.7 \%)$ survived up to the final observation time as in the case of soman poisoning without antidotal treatment.

The anticonvulsive study shows that the antidotal combination consisting of THP and HI-6 is capable to reduce sever toxic effects produced by soman when the antidotal treatment is administered $1 \mathrm{~min}$ after soman poisoning (Table 4). The severest signs observed were fasciculations and/or tremor. These symptoms remain throughout the first four hours after exposure and treatment. At the final time of observation (24-hr after challenge), THP and HI-6 treated animals were free from toxic signs and showed complete recovery to the normal behaviour.
In the second part of the anticonvulsive study, the antidotes were administered $5 \mathrm{~min}$ after exposure to $1 \mathrm{x} \mathrm{LD}_{50}$ of soman (Table 5). All soman-poisoned and treated animals demonstrated subconvulsive and/or convulsive activity. The rats treated by THP and HI- 6 showed tremor and subconvulsions during the first 15-20 min of observation. Nevertheless, animals treated with THP and HI-6 were free from toxic signs and showed completely recovery to the normal behaviour at the final time of observation (24-hr after challenge).

The results obtained from the evaluation of the influence of the composition of antidotal treatment on its efficacy to eliminate soman-induced convulsions are summarized in Table 6 . The severity score for the antidotal treatment depends on the selection of anticholinergic drug. Trihexyphenidyle, the anticholinergic drug with pronounced central effects, seems to be more efficacious to eliminate soman-induced convulsions than peripherally acting atropine. 
Tab. 5: Severity of intoxication in soman-poisoned rats treated with the oxime HI-6 in combination with THP or atropine i.m. administered 5 min. after challenge with $1 \times \mathrm{LD}_{50}$ of soman.

\begin{tabular}{|c|c|c|c|c|c|c|c|c|c|c|}
\hline $\begin{array}{l}\text { Time } \\
\text { Group }\end{array}$ & $5 \mathrm{~min}$ & $10 \mathrm{~min}$ & $15 \mathrm{~min}$ & $0.5 \mathrm{~h}$ & $1 \mathrm{~h}$ & $1.5 \mathrm{~h}$ & $2 \mathrm{~h}$ & $3 \mathrm{~h}$ & $4 \mathrm{~h}$ & $24 \mathrm{~h}$ \\
\hline $\begin{array}{l}\text { HI-6 + THP } \\
(\mathrm{X} 1)\end{array}$ & $\begin{array}{c}3.33 \\
\pm 1.6 \\
* \\
(\dagger)\end{array}$ & $\begin{array}{r}4.00 \\
\pm 1.2\end{array}$ & $\begin{array}{r}3.58 \\
\pm 1.2\end{array}$ & $\begin{array}{c}2.33 \\
\pm 0.5 \\
* *\end{array}$ & $\begin{array}{c}2.16 \\
\pm 1.0 \\
*\end{array}$ & $\begin{array}{c}2.00 \\
\pm 0.6 \\
* *\end{array}$ & $\begin{array}{c}2.16 \\
\pm 0.8 \\
*\end{array}$ & $\begin{array}{c}2.00 \\
\pm 0.6 \\
*\end{array}$ & $\begin{array}{r}2.16 \\
\pm 0.8\end{array}$ & $\begin{array}{r}0.50 \\
\pm 0.8 \\
* * *\end{array}$ \\
\hline $\mathrm{X} 1: \mathrm{X} 2$ & & & & * & & * & * & & * & $* * *$ \\
\hline $\begin{array}{l}\text { HI-6 + ATR } \\
(\mathrm{X} 2)\end{array}$ & $\begin{array}{c}3.00 \\
\pm 1.2 \\
* \\
(\dagger \dagger)\end{array}$ & $\begin{array}{r}3.58 \\
\pm 1.0\end{array}$ & $\begin{array}{r}3.75 \\
\pm 0.9\end{array}$ & $\begin{array}{l}3.67 \\
\pm 0.9\end{array}$ & $\begin{array}{r}3.42 \\
\pm 1.2\end{array}$ & $\begin{array}{r}3.48 \\
\pm 0.8\end{array}$ & $\begin{array}{r}3.58 \\
\pm 1.0\end{array}$ & $\begin{array}{r}3.50 \\
\pm 1.6\end{array}$ & $\begin{array}{r}3.75 \\
\pm 1.6\end{array}$ & $\begin{array}{r}5.16 \\
\pm 2.0\end{array}$ \\
\hline $\begin{array}{l}\text { Soman } \\
1 \mathrm{LD} 50 \\
(\mathrm{X} 3)\end{array}$ & $\begin{array}{r}1.33 \\
\pm 0.8\end{array}$ & $\begin{array}{r}3.43 \\
\pm 1.7\end{array}$ & $\begin{array}{r}4.33 \\
\pm 2.2\end{array}$ & $\begin{array}{l}5.00 \\
\pm 1.1\end{array}$ & $\begin{array}{r}4.66 \\
\pm 1.7\end{array}$ & $\begin{array}{r}4.50 \\
\pm 1.9\end{array}$ & $\begin{array}{r}4.50 \\
\pm 1.9\end{array}$ & $\begin{array}{r}4.50 \\
\pm 1.9\end{array}$ & $\begin{array}{r}4.33 \\
\pm 2.0\end{array}$ & $\begin{array}{r}5.16 \\
\pm 2.0\end{array}$ \\
\hline
\end{tabular}

Statistical significance: * $-\mathrm{p}<0.05 ;{ }^{*}-\mathrm{p}<0.01 ; * * *-\mathrm{p}<0.001 ;(\dagger)-$ comparison between X1 and X3; $(\dagger \dagger)-$ comparison between $\mathrm{X} 2$ and $\mathrm{X} 3$

Tab. 6: $24 \mathrm{hr}$ severity scores of soman-poisoned treated with drug combinations tested*.

\begin{tabular}{|l|c|c|}
\hline Experimental groups & 1 min after $2 \mathrm{x} \mathrm{LD}_{50}$ of soman & 5 min after $1 \mathrm{x} \mathrm{LD}_{50}$ of soman \\
\hline Soman HI-6 + Trihexyphenidyle & 42.40 & 39.53 \\
\hline Soman HI-6 + Atropine & 80.75 & 61.54 \\
\hline Soman (without treatment) & 98.50 & 75.88 \\
\hline
\end{tabular}

* Severity score for each experimental group is presented as a sum of all average values determined at 11 points of observation $(5,10,15,30,60,90,120,150,180,240$ min and 24 hours $)$.

\section{Discussion}

Nerve agents are still considered to be the most important chemical warfare agents. The search for effective protection is in the central concern of different laboratories both civilian and military due to the existing threat of the misuse of chemical weapons not only in military conflicts but also in terroristic attacks $(4,16)$.

The effectiveness of oximes against the toxic effects of nerve agents including soman is usually tested in combination with atropine $(12,20)$. Nevertheless, some other anticholinergic drugs (e.g. benactyzine, biperiden, THP) with pronounced central antimuscarinic effects $(2,8,22)$ should be more advantageous than atropine for the elimination of nerve agents-induced toxic effects because the therapeutical effectiveness of atropine is limited by a relatively low central antimuscarinic effects (9). Atropine is able to cross the blood-brain barrier but a relatively large dose is necessary to achieve central antimuscarinic effects owing to its lower lipophilicity and affinity to central muscarinic receptors compared to other antimuscarinic drugs such as biperiden, benactyzine, THP or scopolamine $(3,5)$.

Our results can be explained by the difference in the central antimuscarinic effects of anticholinergic drugs studied that are very important for the prevention of soman-in- duced centrally mediated seizures and subsequent convulsions and, thus, the survival of soman-poisoned rats. THP as well as benactyzine, biperiden and scopolamine differ from atropine by their efficacy in the central nervous system as antimuscarinics due to their relatively high affinity to the central muscarinic receptors (11) and their lipophilicity making them possible to readily cross the blood-brain barrier $(3,15,23)$.

In conclusion, our data indicate that not only the choice of $\mathrm{AChE}$ reactivators but also the selection of anticholinergic drugs is very important for the survival of soman-poisoned experimental animals as well as for the elimination of soman-induced tonic-clonic convulsions and subsequent neuropathy.

\section{References}

1. Bajgar J. Present view on toxidynamics of soman poisoning. Acta Med (Hradec Králové) 1996:39:101-5.

2. Bajgar J, Fusek J, Vachek J. Treatment and prophylaxis against nerve agent poisoning. ASA Newslett 1994;94-4:10-1.

3. Bajgar J, Patočka J, Herink J, Fusek J, Hrdina V. Effect of benactyzine, atropine and chlorpromazine on blood-brain barrier permeability in rats. Activ Nerv Sup 1978;20:56-62

4. Dawson RM. Review of oximes available for the treatment of nerve agent poisoning. J Appl Toxicol 1994;14:317-31.

5. Ellenwood EHJr, Nikaido AM, Gupta SK, Heatherly DG, Nishita JK. Comparison of central nervous system and peripheral pharmacodynamics to atropine pharmacokinetics. J Pharmacol Exp Ther 1990;255:1133-41. 
6. Fleisher JH, Harris LW. Dealkylation as a mechanism for aging of cholinesterase after poisoning with pinacolyl methylphosphonofluoridate. Biochem Pharmacol $1965 ; 14: 641-9$

7. Kadar T, Raveh L, Cohen G et al. Distribution of ${ }^{3} \mathrm{H}$-soman in mice. Arch Toxico 1985;58:45-9.

8. Kassa J. Importance of cholinolytic drug selection for the efficacy of HI-6 against soman in rats. Toxicology 1997;116:147-52

9. Kassa J, Fusek J. The influence of anticholinergic drug selection on the efficacy of antidotal treatment of soman poisoned rats. Toxicology 2000;154:67-73.

10. Kassa J, Fusek J. The influence of oxime selection on the efficacy of antidotal treatment of soman poisoned rats. Acta Med (Hradec Králové) 2002; 45:19-27.

11. Katayama S, Ishizaki F, Yamamura Y, Khoriyama T, Kito S. Effects of anticholinergic antiparkinsonic drugs on binding of muscarinic receptor subtypes in rat brain. Res Commun Chem Pathol Pharmacol 1990;69:261-7.

12. Koplovitz I, Menton R, Matthew C, Shutz M, Nalls C, Kelly S. Dose-response effects of atropine and HI-6 treatment of organophosphorus poisoning in guineapigs. Drug Chem Toxicol 1995;18:119-31.

13. Marrs TC. Organophosphate poisoning. Pharmacol Ther 1993;58:51-66

14. McDonough JHJr, Shih T-M. Neuropharmacological mechanisms of nerve agentinduced seizure and neuropathology. Neurosci Biobehav Rev 1997;21:559-79.

15. Nakashima E, Ishizaki J, Takeda M, Matsushita R, Yokogawa K, Ichimura F. Pharmacodynamics of anticholinergic drugs and brain muscarinic receptor alteration in streptozotoxin diabetic rats. Biopharm Drug Dispos 1993;14:673-8.

16. Ohtomi S, Takase M, Kumagai F. Sarin poisoning in Japan. A clinical experience in Japan Self Defense Force (JSDF) Central Hospital. Int Rev Arm Ser 1996;69:97-102.

17. Petras JM. Soman neurotoxicity. Fundam Appl Toxicol 1983;1:73-83.
18. Polhuijs M, Langenberg JP, Benschop H. New method for retrospective detection of exposure to organophosphorus anticholinesterases: application to alleged sarin victims of Japanese terrorists. Toxicol Appl Pharmacol 1997;146:156-61.

19. Samnaliev I. Efficacy of biperiden and HI-6 as prophylactic combination against convulsions produced by highly toxic organophosphorus compounds. Voj zdrav Listy 2001;70(Suppl 1):30-2.

20. Shih TM. Comparison of several oximes on reactivation of soman-inhibited blood, brain and tissue cholinesterase activity in rats. Arch Toxicol 1993;67:637-46.

21. Tallarida R, Murray R. Manual of pharmacological calculation with computer programs. New York: Springer-Verlag, 1987:145.

22. Vachek J, Kassa J, Fusek J, Bajgar J. Novější způsoby léčby intoxikace organofosfáty. Sbor věd Prací VLA JEP (Hradec Králové) 1993;116:67-95.

23. Yokogawa K, Nakashima E, Ishizaki J, Hasegawa M, Kido H, Ichimura F. Brain regional pharmacokinetics of biperiden in rats. Biopharm Drug Dispos 1992;13:131-8.

Submitted November 2003

Accepted June 2004.

Doc. MUDr. Jiř́ Kassa, CSc.,

Purkyně Military Medical Academy, P.O. Box 35/T, 50001 Hradec Králové, Czech Republic. e-mail: kassa@pmfhk.cz 